\title{
Women Empowerment Through Advertising
}

\author{
Sangeeta Sharma ${ }^{1 *}$ and Madusmita Das ${ }^{2}$
}

\begin{abstract}
The word empowerment is overused and misinterpreted. Women always aspire to have her freedom of expression and equality. There is no attempt to prove her superior to men but to stand on equal pedestal and have equal opportunity to prove her mettle. There are a lot of initiatives taken by the government to take care of women's safety and security; however there remain a hiatus in the implementation of policies. The media plays a significant role in empowering the women through cinema, drama or advertising. Advertising creates an indelible impact because of its basic purpose to lure the customer. Advertising has a great potential to change the mind set of people as it has immense creativity in its execution. In the last few years ad agencies have tapped the area to empower women by coming up with engrossing ad campaigns- be it the Unisex washing machine by Llyod, Havells, Biba, etc. This paper attempts to find the ways in which these advertisements have created an impact on women and society at large. The analysis of the women centric advertisement and femvertising will enable to see the projection of women in future.
\end{abstract}

\section{KEYWORDS}

Empowerment, advertising, Ad campaigns, femvertising

\footnotetext{
${ }^{1}$ Birla Institute of Technology and Science (BITS), Pilani, India

${ }^{2}$ Birla Institute of Technology and Science (BITS), Hyderabad, India

*Corresponding author; Email:

38.sangeeta@gmail.com
}

\section{INTRODUCTION}

Gone are the time when women were subservient to men and that was why her projection in all the media was quite similar; she was shown either in four walls indulged in household chores, or just taking care of family and children. If anyone in the family had to sacrifice it was only she. The advertisement during 70's and 80's depicted women in very docile roles. It is an accepted fact that ads are reflection of society- whatever social system is prevalent at the time of advertising execution; the advertisers take the lesson from it and depict the same. Portrayal of women was majorly as sex symbol or of objectification. That was the reason that women were projected even in the products that did not need them. J.K. Cements had the advertisement which had women endorsement just for the increase of TRP.

Advertisements are inevitably used for social communication. It is a powerful force used by the advertising people to persuade, manipulate and shape behaviour of the consumers. To goad the customers to buy the product, the advertisers attempt to adopt different strategies and to depict pretty women in the ad is one of them. Sometimes the advertisers do not bother if the product really needs to have women as endorser. Thus, the images of woman in advertising have been a matter of debate from considerable time. With passage of time the portrayal of women in advertisements has undergone a great revolution according to the changing position and responsibility of women in the society. Earlier women's destiny was only limited to her role as mother and wife and men were considered as the main consumer of the family. In the same way both were also portrayed in the media, the former in relationship role and as submissive whereas the later as the bread earner of the family, aggressive and adventurous. During last couple of decades due to rapid changes in market scenario there is a great shift in the responsibility 
assigned to women and how she is placed in the society. The one who was totally dependent on men has turned into the liberated women of 21stCentury either with independent salary or with views of her own. Woman confined to the household, works now and is seen as the independent career woman of today. Their role has metamorphosed from domestic managers to prime purchasers, who take the decision about the majority purchases for the family. Thus, now they are the main targets of the marketers and increasingly portrayed in variety of ads.

From the late 60 s focus changes regarding the portrayal of women in the media (Bardwick\& Schumann, 1967).Earlier, studies indicate that women in advertisements were mostly depicted in relationship role as spouse, girlfriend, parent or friend who were often shown as dependent (Bardwick \& Schumann, 1967; Goffman, 1979; Sullivan \& O' Connor, 1988), and in home setting, represented for the beauty, kitchen and bath room products and rarely portrayed as professional and career oriented (Mc Aruther and Resko, 1975; Silverstein and Silverstein, 1974). Studies also explore that women in advertisements were portrayed in stereotypical roles globally. Milner and Higgs (2004) explore in Australian television advertisements women were portrayed in a stereotypical way, which was far from the actual experiences of women in real life. Parallel results were also found from the studies on TV advertisements of Pakistan (Ali \&Shahwar, 2011), New Zealand (Furnham \& Farragher, 2000), Poland (Furnham\& Saar, 2005), South Africa(Holtzhausen, Joordan \& North,2011), Bulgaria (Ibroscheva, 2007), Korea (Kim \& Lowry, 2005), and U.S. (Morris \& Nichols, 2013); In contrast, the French advertisements were found to display contemporary gender roles (Morris and Nichols, 2013).Parallel results were also found from the studies on TV advertisements of the Asian countries Pakistan (Ali \&Shahwar, 2011), New Zealand (Furnham \& Farragher, 2000), Poland (Furnham\& Saar, 2005), South Africa (Holtzhausen et al., 2011), Bulgaria (Ibroscheva, 2007), Korea (Kim \& Lowry, 2005), and U.S. (Morris \& Nichols, 2013).

\section{Goffman's Theory of Gender Stereotype}

Erving Goffman, the great sociologist of his time (1979) have analysed of 400 advertisements to explore how women are represented in advertisements and classified the representation into six categories.

\section{Relative size}

Goffman found that in advertisements during the social interaction between the genders; men are often portrayed taller than women which indicate the men's superiority of status over women in advertisements.

\section{The feminine Touch}

According to Goffman, women more than men, are depicted using their fingers and hands to trace the outlines of an objects or to cradle it or to caress its surface. He also found the use of face and self-touching is quite common with women in ads, which imply a sense delicacy and preciousness about the body.

\section{Function Ranking}

He noticed that in advertisements, during the professional interactions most of the time men are shown in executive role and women are in sub -ordinate roles. Even for the household and cosmetics products (for women), men are portrayed as the experts to describe the importance of the products.

\section{The Family}

The fathers in the advertisement according to him are shown to be standing little apart from the physical circle of family members and mothers are shown as mingling and involving with the family members.

\section{The Ritualization of Subordination}

Goffman observed that in advertisements, women in comparison to men are shown lowering themselves physically in some form or other like lying on beds and floors, in bashful knee bend, lowering head, canting head or body. While men are shown walking straight and steady, women are shown usually holding hands, leaning on shoulders, overtly showing their affection, 
thereby implying the dependent status of women, who are in need of support, help and protection.

\section{Licensed Withdrawal}

Women, often in advertisements, appeared to withdraw themselves from the social situations through involvement in telephonic conversation, showing emotional response by covering their face or mouth with hands, shocking or biting fingers, averting head/ eye, lowering of heads, in close physical touch with men, withdrawing their attention from the scene and mentally drifting them from the physical scene around them and thus, they avoid direct eye contact with the viewers. (Goffman, 1979).

\section{Breaking the barriers}

Since gender is not static, over the years gender roles have changed and its parameters getting refined both in society and media making the stereotype less distinct.

The boundaries of the gender division of labour between the productive and reproductive roles are narrowed down as women have started entering in to previously male subjugated region (Pandya, 2008, p. 61). Now- a- days women endorsement is becoming an integral part of modern advertising. Recent advertising has focused on the 'empowered' women called femvertising (Yorgos\&Zotos, 2016).

Rath (1987) said, "Now a-days men and women do not live in water tight compartments of bread winning and home making. The women help in keeping the family, society and life together. She is no longer a mere housewife." Introduction of modern education, increase in the female literacy rate and enrolment of women in higher education, subsequent participation of women in labour force, expansion of the outlook and the result of the feminist movement, brought changes in the role and status of women not only in the society but also in the way they were portrayed in the advertisements. There is a growing trend of independent, single, working women and a similar life style portrayal is seen in advertisements. Present day advertisements represent smart mom's independence and passion, the super wife's assertion in choice, the young girl's choice of education over marriage, the modern women's balance between the professional and personal life (Jha, 2007), (Das, 2016)

The persona of the "New Indian Woman" is formed who is a prospective consumer not only with independent thoughts but also with an independent salary and a complete hold over the finance of her family.

Now-a-days instead of portraying the unrealistic beauty and demeaning the ability of women advertisements have started celebrating the real womanhood sending the meaningful message. Advertisers are opting for a novel approach to portray women strategically in the advertisements to motivate the consumer to buy the product. A paradigm shift is noticed in the concept of today's advertisements, where the main focus is empowering women. A new era of advertising emerged now that strives to empower women: Femvertising (Repisky, 2015).

Fatima (2013) has reiterated that women depiction in advertisement has gone for sea change and is still improving. One can observe in current ads that woman is shown as confident, extrovert, leading the group, can do it attitude rather that docile, timid, washing utensils, cooking, waiting for her husband and taking care of the whole family at the cost of her own health. The study of Moorthi, Roy and Pansari (2014) indicates that the role of woman in television advertising has changed over the decades. Nagi (2014) claims that though women in Indian TV advertisements still are represented in stereotypical way; due to influences from the west, the familial norms are changing from being patriarchal to more egalitarian. Advertisers nowa-days have started depicting women in neutral role where both the gender have the equal status and contributed equally. A new trend has started, couple of representations for consumer durable goods like, washing machines, refrigerators, 
microwave even for dish washing gel, etc. imply that now men are ready to share the house hold responsibility (Das \& Sharma, 2014).

The role portrayal of women in advertising is not a new area for study, however a lot of studies have taken place in western context but not in the Indian context and there is a vast difference in their values, beliefs and norms. It is unjust to generalize their conclusions in Indian context. In India also the issue of women portrayal has been dealt with but the samples are print advertisements and the observations are negative portrayal of women. It is only Fatima (2013) who has tried to unravel the positive depiction of women. Therefore, this paper attempts to fill the gap by sifting through the ads to identify how they are showing women empowerment hence contributing to gender equality in the society. The paper is completely a qualitative study, where the objective is to find out how the contemporary advertisements try to empower women through their advertising message. The content analysis of some of advertisements is made to meet the objective.

The ads are selected on the basis of their popularity and viewership. Given below is the analysis contemporary Indian advertisement:

\section{Lloyd - unisex washing machine}

Washing has always been associated with the women but the ad of Lloyd - unisex washing machine mooted the new concept that why only women should wash the clothes and men should not. The task must be equally shared as washing is not only women's task.

In the ad in a consumer durable store a salesman offers to show a male customer some washing machines, since he is busy with his phone, he tells the salesman to address and tell his wife about the machine as it is her concern. The wife quips to show the unisex washing machine in the store. The salesman is very keen to show the Lloyd Unisex washing machine highlighting its advanced features. The lady further brings a twist by telling her husband that he need not get perplexed as 'Even sir (he) can use it'.

This successful campaign hits the male counterpart as our society, especially in a patriarchal country like India, all the household chores like cooking, cleaning and washing primarily are to be taken care of by women. The message gives a punch to men that today's women share equal load and now-a-days are busy in their professional life so it is expected of them to share the work. Men should pause and think about the women and should not take her for granted. They must share the load is the message.

\section{Ariel share the load}

With the passage of time though both the roles of men and women are refined a lot in Indian society; yet the positioning of women is still stereotypical in the minds of people. Irrespective of their economic and educational status Indians have a different viewpoint for the women of their family, who should first take care of the health and hygiene of their families.

They are solely responsible for the pristine sparkling white clothes of the family. Moving beyond this, the recent ad of Ariel an Indian detergent company sheds light on unequal gender roles that exist across generations and emphasizes the need for equal distribution of household chores.

In Ariel's "Share the Load" ad, a father watches how his daughter is balancing the household chores with her own job without any help from her husband. This leads him to realize it is because of the example he had set in front of her since her childhood days. In an attempt to bring about positive change, he agrees to share laundry duties with his wife. This is a great challenge to the typical patriarchal notion. The campaign won the Glass Lion at the Cannes, an award that recognizes ads that challenge gender stereotypes. Though this ad has generated a lot of media buzz and sparked controversies, it marched a step forward towards gender equality. It injects in the mind of the fathers and husbands of a patriarchal 
society, that the household chores are also part of their responsibility.

\section{Havells Appliances: coffee maker - Respect for Women ad}

Havells has launched captivating campaign consisting of six TVCs under the theme "Respect Women". In all of its advertisements it tries to give the message that the women's role is not circumspect to the household works, or to kitchen as they are capable of doing tasks, which were male dominated. The message in the ad of havells is that the task is not gender specific and can be handled by anyone. The interesting coffee maker TVC shows a scene of an arranged marriage, where a boy's family has come to the girl's house to see her for marriage alliance. The boy's mother is restive and shares that her son wants to have someone to make coffee for him and that is why she wants him to get married. The girl is shocked to hear this and suggests the simpler solution is to get him a coffee maker than the life partner. She reiterates that she is not to be compared with kitchen appliance. She is a woman and not a commodity.

\section{Havells - "Ab Hawa Badlegi"}

The amazing ad- "Ab Hawa Badlegi", from the ad series of Havells electronics underscores the need to initiate change in the social custom to attain gender equality. It has taken lead step against the social norm that after marriage the surname of the wife has to change as her husband's surname. The ad beautifully shows a man with her wife in the marriage registrar's office, who eagerly says to adopt his wife's surname after marriage thus makes a daring departure from exploitive traditions where a woman loses not just her surname but also her identity once married. The ad leaves an indelible impact on the viewers and makes them think why women have to always change her surname after marriage.

\section{Titan Raga: Women of Today}

The watch is sleek and sophisticated and therefore the campaign targets towards the educated urban confident and independent women of today who is cognizant of her self- worth and have independent thought. In the campaign "Women of Today" projects the other side of woman who is a decision maker, who has broad thinking and loves her job. The ad beautifully depicts how women have positively changed over the passage of time. No more she has to depend on men for bringing the salary- she too can earn her own salary. She is self-assured and can make her own decisions. It depicts a self -assured woman, i.e. actress Nimrat Kaur, who claims to have taken decision of her life and decided to work rather than getting married. She became the role model for other women who want to do the same in their life.

\section{Tanishq's jewellery AD: A Second Marriage}

Tanishq's Jewellery ad endorses second marriage of the divorcee which is an attempt to break down several social hurdles in India i.e. the remarriage of a widow/ divorcee, despite having a kid, portrayal of a dusky complexion lady and care from the stepfather in just one and a half minute ad. To delve with a topic like this is really challenging for a brand. It has also broken the concept of the fair and lovely cream that fair is beautiful by depicting a dusky woman. It is indeed a brave and encouraging message from a brand.

\section{Sonata Safety Watch campaign}

Recently Sonata the popular watch brand launched a new campaign for safety watch that designed exclusively for women, enabling the girls and women in India to come out of their house even in late nights to fulfil their dreams. Another initiative focused on the empowerment of women. The placement of special button at the 8 'o'clock position which when double clicked, immediately sends distress alarms to 10 designated people. The ad shows how two Haryana girls are sitting at the bus stop waiting for the bus at late night fearlessly with the watch in their hands. They are the athletes, going for their national selection event to fulfil their dreams. When the Chief Marketing Officer was asked about the great idea supporting Sonata ACT theme he replied "The Indian woman has evolved to take on more challenges and responsibilities. With Sonata ACT, we are offering these talented 
and multi-faceted women an enabler that allows them to courageously follow their dreams. The latest campaign for ACT is a celebration of the new-age Indian women". (http://bestmediainfo.com/2016/12/safety-is-atyour-hand-with-titan-sonata-act/).

\section{Deepika Padukone - "My Choice"}

The vogue ad "My choice" by Deepika Padukone is setting another milestone for empowerment of women in the society where she is talking about the choices which the women are not able to make because of the taboos of the society. Fulfilling her own dream, making choices about the dress to wear, marriage, career should be their legal rights. The ad is really an encouragement for the women and girls who always had to let their dreams die down.

\section{DISCUSSION}

With the change in government policies and support system, hordes of new series of advertisements are launched which empower women in all aspects- socially, politically and economically. The stereotyping is completely getting eradicated from the advertising world as it is no more accepted by the general audience. Women can be empowered by generating awareness about her rights and providing her more freedom of expression. She is to be heard in different forums and be appreciated for her efforts. The advertisements usually work in tandem with the films which are made on the similar theme of empowering women- Dangal, Pink, Secret superstar, are to name a few. It has been noted that advertisements which depict women skimpily dressed, with svelte figure, epitomizing beauty are no more creating interest amongst the viewers. Neither are the ads which have women getting tensed on the arrival of her husband at home as she has not cooked the food and her hands are soaked in washing powder. Instead the advertisement like Ariel where the father observes the daughter in multitasking, who has so much responsibility on her shoulder is cajoled to realize that what he had not done when his wife was also doing the same. Watching his daughter in the same state is an eye opener for father and at the later age of life he begins to shoulder the responsibility at home. Earlier advertisements were grounded in stereotypingwoman should be fair with flawless complexion, should be most efficient, perfect figure. But now the time is changing, she is her husband's boss in the office, instructing him to finish the task and also contributing in the economy of the family.

The sexual objectification of women in the advertising of cement and cars has negative impact on the psychology of women. The girls aspire to have zero figures leading to anorexia. If they are not able to shed weight for slim figure, they tend to develop inferiority complex. The dramatic changes came in the portrayal of women by the end of 1990's when women organization raised their voices against the advertisement depicting women in negative light. The advertisement of fair and lovely, which projected that only fair women are competent came under the critical scrutiny. The objection came from US National organization for women which insisted on to eliminate the gender-based stereotypes from media. Gradually the portrayal started shifting from negative to positive. Women had been the omphalos of most of the advertisement, but now the depiction became positive and more acceptable, resultantly her enthusiasm in purchasing increased too. This positive depiction led to the concept of " femvertising" an extremely important notion in the world of advertising. Femvertising relates to the advertisement which celebrates womanhood and empowers them.

It is true that advertising is projection of the reality in society. Now more women are getting educated, hence independent and capable of making decisions. The colour of skin and body shape is not the criteria for advancement in the profession and life. It is the capability. This is visible in the in airline industry where earlier the applications were invited only from beautiful, fair skinned girls. Now that is not the case. The advertising agency has realized that it is better to project women as they are, rather than ideal image and that is why the agencies are putting 
more efforts to represent the women in positive light.

We come across the advertisements which have women in different portrayals saying "why should boys have all the fun?" she drives her own car, pays her own bills, has fulfilling job and takes her own decision. The advertisement of Biba with the tagline "Change the Convention" sends beautiful message. This is clear indication that advertisements designed now are generating awareness breaking the stereotypes and depicting positive image of women in the ads. The USP femvertising is very encouraging for women to be more confident, grabbing opportunities and keep the worries away about misconception. The self-esteem gets boosted. The brands which have really gained popularity because of femvertising are discussed in detail.

\section{CONCLUSION}

Advertising is the true reflection of the ideology prevalent in the society. This has been realized by the ad agencies and that is why they do not miss the opportunity to represent the women in positive light. When media reflect the women positively, the society also treats women with a lot of respect. The change may be slow but is a very significant to have this change in the media as we are exposed to uncountable advertisements in a day. It is beneficial for the society in large including men and women to have positive image of women as this can create healthy society and making the progress possible. Slowly the problems faced by women everyday will surely reduce and women can walk freely at any part of the country any time. The low selfconfidence of women gets boosted by the new genre of advertising. The femvertising is a great attempt to bring the change, though it is with the intention to boost the sale but this will also empower the women and get away with the demeaning content that has been on the shelf for ages.

\section{REFERENCES}

Ali, S., \& Shahwar, D. 2011. 'The representation of men and women in the advertisements of Pakistani electronic media'. Journal of Media and
Communication Studies, Vol. 3, no 1. Retrieved from http://www.academicjournals.org/jmcs.

Bard wick, J., \& Schumann, S. 1967. 'Portrait of American men and women in TV commercials'. Psychology, Vol. 4, no.4.

Das, M., \& Sharma, S. (2016). Fetishizing Women : Advertising in Indian Television and its Effects on Target Audiences. Journal of International Women studies, 18 (1),114-132

Das, M. 2016. 'Portrayal of Women in Indian Television Advertisements: An Exploratory Study', Thesis (unpublished), pp:49-54.

Fathima, K. N. 2013. 'Role of Women in Promoting Products - With Reference to TV Ads', Indian Journal of Applied Research, Vol. 3, no.7.

Furnham, A.\& Saar, A. 2005. 'Gender-role stereotyping in adult and children's television advertisements: A two-study comparison between Great Britain and Poland'. Communications, Vol. 30.

Furnham, A., \& Farragher, E. 2000. 'A cross-cultural content-analysis of sex-role stereotyping in television advertisements: A comparison between Great Britain and New Zealand'. Journal of Broadcasting and Electronic Media, Vol. 44.

Goffman, E. 1979. Gender advertisements. New York:Harper/Colophon.

Grau, S.L., \& Zotos Y.C. 2016. Gender stereotypes in advertising: a review of current research. Retrieved from

http://www.tandfonline.com/doi/abs/10.1080/02650 487.2016.1203556

Holtzhausen, T., Joordan, Y., \& North, E.J. (2011). The portrayal of women in South African television commercials. Southern African Business Review, 15(3),167-183

Ibroscheva, E. 2007. 'Caught between east and west? Portrayals of gender in Bulgarian television advertisements'. Sex Roles, Vol. 57, no 5.

Jha, J. 2007. Gender Roles in Advertising: Looking Beyond the Stereotypes. In D. Nigam, J. Jha, \& (Eds.), Women in Advertising: Changing perceptions (pp. 127 143). Agartala: The Icfai University Press.

Kim, K., \& Lowry, D. 2005. Television Commercial as a Lagging Social Indicator: Gender Role Stereotypes in Korean Television Advertising. Sex Roles, Vol. 53.

MCArthur, L., \& Resko, B. G. 1975. 'The portrayal of men and women in American television commercials'. The Journals of Social Psychology, Vol. 97.

Milner, L. M., \& Higgs, B. 2004. 'Gender sex-role portrayals in international television advertising over time: The Australasian experience'. Journal of Current Issues and Research in Advertising, Vol. 26. 
Moorthi, Y. L.., Roy, S., \& Pansari, A. 2014. The Changing Roles Portrayed by Women in Indian Advertisements: A Longitudinal Content Analysis. Working paper No.: 446, Indian Institute of Management Bangalore, Retrieved from: http://papers.ssrn.com/sol3/papers.cfm?abstract_id= 2391649

Morris, P. K., \& Nichols, K. 2013. 'Conceptualizing Beauty: A Content Analysis of U.S. and French Women's Fashion Magazine Advertisements'. Online Journal of Communication and Media Technologies, Vol. 3, no. 1.

Nagi, P. 2014. 'Projection of Women in Advertisement: A Gender Perception Study'. International Journal of Managerial Studies and Research, Vol. 2, no. 9.

Pandya, R. 2008. Women in Changing India., New Delhi: Serials Publications

Rath, S. 1987. Working Women in Cuttack. Journal of Social Welfare, Vol. 34, no.1.

Repisky, J. 2015. Femvertising: The New Era of Advertising. Women's Outreach and Resource Collective | A collaborative community for advocates of gender equity and social justice (WORC UGA), Retrieved from: http://worcuga.com/2015/02/femvertising-the-newera-of-advertising/

Silverslein, A., \& Silverstein, R. 1974. 'The Portrayal of Women in TV Advertising'. Federal Communications Bar Journal, Vol. 27, no.1.

Sullivan, G., \& O'connor, P. J. 1988. 'Women's role portrayals in magazine advertising: 1958-1983'. Sex Roles, Vol. 18. 